\title{
Efficacy of Commercial Insecticides against Tomato Leaf Miner Tuta absoluta (Meyrick) (Lepidoptera: Gelechiidae) in Palpa, Nepal
}

\author{
Anil Bastola ${ }^{1, a^{*}}$, Subodh Raj Pandey1,b, Anjali Khadka ${ }^{2, c}$, Rajendra Regmi ${ }^{3, d}$ \\ ${ }^{1}$ Agriculture and Forestry University, Rampur, Chitwan, Nepal \\ ${ }^{2}$ Lamjung Campus, Institute of Agriculture and Animal Science, Tribhuvan University, Nepal \\ ${ }^{3}$ Asst. Professor, Department of Entomology, Agriculture and Forestry University, Rampur, Chitwan, Nepal \\ *Corresponding author
}

\begin{tabular}{|c|c|}
\hline A R T I C L E I N F O & A B S T R A C T \\
\hline $\begin{array}{l}\text { Keywords: } \\
\text { Tomato leaf miner } \\
\text { Commercial insecticides } \\
\text { Problem ranking } \\
\text { Larval mortality } \\
\text { Palpa }\end{array}$ & $\begin{array}{l}\text { A survey and field experiment were conducted to evaluate the efficacy of commercial insecticides } \\
\text { against tomato leaf miner [Tuta absoluta (Meyrick)(Lepidoptera: Gelechiidae)] under farmer's field } \\
\text { condition in Palpa, Nepal from February } 2018 \text { to April } 2018 \text {. It consists of seven treatments } \\
\text { replicated three times. The treatments included: Abamectin } 0.15 \% \text { EC (dose: } 0.3 \mathrm{ml} / \mathrm{liter} \text { ), } \\
\text { Imidachloprid } 17.8 \% \mathrm{SL} \text { (dose: } 0.3 \mathrm{ml} / \mathrm{liter} \text { ), Spinosad } 45 \% \mathrm{SC}(0.3 \mathrm{ml} / \mathrm{liter} \text { ), Azadirachtin } 300 \mathrm{ppm} \\
\text { (5ml/liter), Chlorantraniliprole } 18.5 \% \mathrm{SC}(0.3 \mathrm{ml} / \mathrm{liter} \text { ), Emamectin benzoate } 5 \% \mathrm{SC} \text { ( } 2 \mathrm{gm} / \mathrm{liter} \text { ) and } \\
\text { control. Treatments were applied two times at } 12 \text { days interval. From the farmer survey, Tuta } \\
\text { absoluta was identified as the major production problem of the study area. The field experiment } \\
\text { revealed that there was a significant effect of insecticides in larval mortality and damage reduction. } \\
\text { The lowest percentage of leaves damage was obtained in spinosad followed by chlorantraniliprole } \\
\text { and emamectin benzoate and the lowest fruits damage was obtained in chlorantraniliprole followed } \\
\text { by spinosad and emamectin benzoate. Similarly, the lowest larval population in both leaves and } \\
\text { fruits was observed in chlorantraniliprole followed by spinosad and emamectin benzoate. Average } \\
\text { mining in infested leaves and fruits was found non-significant at all days of observation. The rate } \\
\text { of larval population reduction over control was found highest in chlorantraniliprole followed by } \\
\text { spinosad and emamectin benzoate. Thus, chlorantraniliprole, spinosad and emamectin benzoate } \\
\text { were superior insecticides for management of Tuta absoluta in the field condition. }\end{array}$ \\
\hline
\end{tabular}

Keywords:

Commercial insecticides

Problem ranking

Larval mortality

were superior insecticides for management of Tuta absoluta in the field condition.

\section{Introduction}

Nepal is an agricultural country where the majority of people $(65.6 \%)$ directly depend on agriculture and contribute less than one third $(27.6 \%)$ of total Gross Domestic Product (GDP) (MOF, 2017). Vegetable crops are an essential component of sustainable development, with a significant contribution to food security, nutritional balance and income source for resource-poor growers, especially in urban and peri-urban areas (FAO, 2012). Tomato is the $3^{\text {rd }}$ important vegetable cultivated in 21,389 ha with a production of $400674 \mathrm{Mt}$ and productivity of 18.73 Mt/ha in Nepal (MoAD, 2016).

The major insect-pests of field cultivated tomato were tomato fruit borer (Helicoverpa armigera), leaf miner (Liriomyza trifolii), and whiteflies (Bemisia tabaci) which can spread tomato yellow leaf curl virus. In addition to this, the tomato leaf miner (Tuta absoluta), has been recently introduced to Nepal. The cause of long-distance dispersal is through packaging material coming from infested countries (Potting et al., 2013).
The tomato leaf miner (Tuta absoluta), native to South America is a serious threat to world's tomato production (Chidege et al., 2016) in both open and greenhouse condition. Larvae feed on the mesophyll of the leaf leaving only the epidermis intact with its faeces, which subsequently widens and then the damaged tissue dries. Under intense attack, the damaged leaves turn yellow, wither, and senescence; the fruits are destroyed; and the plant ultimately dies (Maluf et al., 1997). The yield and fruit quality are both considerably impacted by direct feeding as well as secondary pathogens entering into the host plants through wounds made by the pest (Kaoud, 2014).

The main host plant of Tuta absoluta was tomato (Solanum lycopersicum L.), but solanaceous cultivated plants such as potato (Solanum tuberosum L.), eggplant ( $S$. melongena L.), pepper and hot pepper (Capsicum spp.) and wild plants Solanum nigrum L. and Datura stramonium L. (Estay, 2000) were the alternative host of the pest. Besides, 
it has also been reported from plants of Fabaceae familylike Phaseolus vulgaris, Vicia faba, Vigna unguiculata and Medicago sativa, which are commonly cultivated plants in Nepal (Bajracharya et al., 2016; Abdul-Ridha et al., 2012).

It was first detected in Ethiopia in 2012 (NAPPO, 2013). It was recorded from Maharashtra (India) and Nepal during October 2014 and May 2016 respectively (Bajracharya et al., 2016) from an altitude ranging from 725 masl to 1664 masl which defines the diversity of the pest. Since then, it had gradually spread almost all over the country. Srijana and Samjhana hybrids were worst affected variety of tomato. It was detected in 16 districts of Nepal among which 14 were middle hill districts and 4 were terai districts i.e Kailali, Saptari, Banke and Dang (Sah, 2017).

Tuta absoluta is a holometabolous insect which comprises four development stages viz. egg, larva, pupa and adult, and is completed within 24 days at $27^{\circ} \mathrm{C}$ (NAPPO, 2013). It has high reproductive potential and its life cycle ranged from 24 to 76 days, depending on the environmental conditions (Arnó and Gabarra, 2010). The adult lay its egg on the underside of leaves, buds, stems and calyx of unripe fruits singly or in batches. The newly deposited eggs are oval and creamy white in colour (Estay, 2000) then turn to yellow and finally black before hatching (Salama et al., 2014). Pupation may take place in the soil or on the leaf surface, stems, flower, fruits (Torres et al., 2001) or within the mines. They are brown in colour, which are initially green (Estay, 2000) and $6 \mathrm{~mm}$ in size. Pupation completes in 10 days. Adults are small moths having a body length of $5-7 \mathrm{~mm}$ and wingspan of about $8-10 \mathrm{~mm}$. Adults are mottled grey (Estay, 2000) or brown or silver in colour.

Tuta absoluta infests all the aboveground parts of the plant in each developmental stage. All stages of Tuta absoluta are found throughout the growing season under greenhouse condition (USDA-APHIS, 2011). The mines in the leaves form whitish and irregular spots which are found covered with droppings. It affects more in young fruits (MOAD, 2016).

Economic losses due to Tuta absoluta in tomato have been reported to be up to $100 \%$ in some countries in Africa particularly Sudan, Kenya, and Ethiopia. Chidege et al. (2016) reported a yield loss of $80-100 \%$ by this pest from countries in Northern and Western Africa. According to Sah (2017), the pest is likely to cause $80-100 \%$ tomato yield loss and financial loss of over 50 million USD. According to Muniappan (2015), T. absoluta had already infested 1.0 M ha of tomato cultivated area $(22 \%$ of the total cultivated surface) out of $4.4 \mathrm{M}$ ha in 2011.

In Spain, pesticides were applied 15 times more per season in the first year of introduction and cost went up by 450 Euros per hectare due to use of costly insecticides. The tomato pest management cost will go up by $\$ 500 \mathrm{M}$ per year if the rest of the world infested by Tuta absoluta (Muniappan, 2015). Due to fear of failure of crop due to this pest, farmers are demotivated in tomato farming because of increased costs and losses in tomato production (Sah, 2017).

The most widespread and successful applications of sex pheromones concern their use in detection and population monitoring (Witzgall et al, 2010). The most common pheromone traps used for trapping of Tuta absoluta are water traps, which are easier to maintain and less sensitive to dust than Delta or light traps and also have a larger trapping capacity than Delta traps. Water traps consist of a plastic container holding water and a pheromone lure. The lure is secured above the water with a wire attached at both ends of the container. A small amount of vegetable oil or soap should be added to the water to reduce surface tension and limit water evaporation so that insect is trapped in water and cannot escape out from surface. This type of trap can capture large numbers of adult males without becoming saturated with insects (USDA-APHIS, 2011). The important elements related to trap placement are trap height and position concerning vegetation (Howse, 1998).

The pheromone traps can be used for pest detection, population monitoring (Harizanova et al., 2009), mass annihilation and mating disruption (Megido et al., 2013).

Neem oil (Azadiractin) is contact or systematic insecticide. Neem plant contains several active metabolites such as alkaloids which can control insect pests (Zekeya et al., 2016). It is used when there is the low infestation of Tuta absoluta larva or greater than 5 moths are trapped per day in any pheromone trap (Sah, 2017). At low infestation level, Bacillus thuringensisis is recommended to use in conjunction with Azadiractin. Hence, this research was conducted to find out the effective chemical control measures against $T$. absoluta in field condition.

\section{Materials and Methods}

The farmer's survey and field experiment were conducted for this study.

\section{Farmer Survey}

Farmer survey was done to identify the prevailing problem of tomato production, find the severity of Tuta absoluta and control measures currently being deployed by farmers for its management.

Selection of Study Area

The study was conducted in Tansen Municipality, Palpa district in western hills of Nepal. The command area under Prime Minister Agriculture Modernization Project (PMAMP), Project Implementation Unit, Vegetable Zone, Palpa was purposively selected as it includes Tansen Ward No. 7, 8 and 9, which were the major vegetable producing areas and worst hit by Tuta absoluta in the previous year.

Preliminary Survey

The pre-research field visits were conducted to gather preliminary information about the status of vegetable farming. It includes major vegetables cultivated, the status of tomato farming, the status of diseases and insects and the status of Tuta absoluta in tomato cultivation. This information was used to prepare the interview schedule and designing the experiment.

Interview Schedule Design

The simple interview schedule was developed including the information on major production problems, the status of Tuta absoluta and management practices adopted to control it.

\section{Pre-testing}

The interview schedule was pre-tested before administering to the actual respondents for checking the reliability and validity of the interview schedule. The pretesting was done on 10 percent respondents near to study area. The corrections were made in the final interview schedule. 


\section{Household Interview}

Thirty commercial tomato growers of Tansen Municipality Ward No. 7, 8 and 9 were interviewed to avail the information. It includes the major hindrance on their field caused by Tuta absoluta and farm-level management strategies adopted by them to manage the pest. A Focused Group Discussion (FGD) and was also conducted with representative farmers from all affected areas.

\section{Field Experiment}

Selection of Experiment Site

The field experiment was conducted on Tansen-7, Palpa to know about the effectiveness of different chemical pesticides against Tuta absoluta. Palpa district ranges from 157 to 1936 meters above the mean sea level. The geographic location of the field experiment site was $21^{\circ} 51^{\prime}$ $\mathrm{N}$ and $83^{\circ} 32^{\prime} \mathrm{E}$ at an altitude of 982 meters from mean sea level. The research plot was $4 \mathrm{~km}$ south of Tansen bazaar.

The average annual rainfall in Palpa was $1903 \mathrm{~mm}$, with the higher frequency of rainfall noticed from June to August. About $80 \%$ of total rain is received due to the monsoon. The average summer temperature is $23^{\circ} \mathrm{C}$ while that of winter is $14^{\circ} \mathrm{C}$. However, the maximum and minimum temperature can range between $32^{\circ} \mathrm{C}$ to $2^{\circ} \mathrm{C}$.

\section{Field Experiment Design}

The experiment was laid out at the tomato field of Nava Prativa Krishi Tatha Pashupalan Farm, Tansen- 7. The determinant variety of tomato named Dalida, with a life span of 54 days was planted. The field was laid out in Randomized Complete Block Design (RCBD) with seven treatments replicated three times. It consists of 21 plots. The six different chemical insecticides (most of them have biological origin or low toxicity) and control was used as treatment.

\section{Layout of Field}

Since the research was commenced on the farmer's field, no observations were made regarding the soil testing, manuring and fertilization, and other initial stage cultural operations used. However, plot size was maintained at $2.25 \mathrm{~m}^{2}(1.5 \mathrm{~m} \times 1.5 \mathrm{~m})$ with the row to row spacing and plant to plant spacing of $30 \mathrm{~cm}$ each. Spacing between both the replication and treatment was maintained at $50 \mathrm{~cm}$ with a field margin of $50 \mathrm{~cm}$ each on all sides. Thus, the total area of research field was $94.25 \mathrm{~m}^{2}$ with total length and breadth of experimental design $14.5 \mathrm{~m}$ and $6.5 \mathrm{~m}$ respectively (Figure 1, Table 1).

\section{Application of Treatments}

The first application of treatments made on 54 days old tomato plants. Pre-spray observations and data collection were made one day before the application of treatments. The second spray was made 12 days after the first spray while the third spray was made on 12 days after the second spray.

Syringes were used to measure the volume of liquid insecticides for the formulation, while $2 \mathrm{gm}$ spoon was used to measure powdery insecticide. Knapsack sprayer was used for the application of insecticides.

\section{Observation of the Parameters}

Five central plants from each plot were tagged as sample plants for observation and data were collected. Data were collected before first spray and $6^{\text {th }}$ and $12^{\text {th }}$ day after each successive spray. After collection of data of $12^{\text {th }}$ day of the previous spray, following spray was made on the same day.

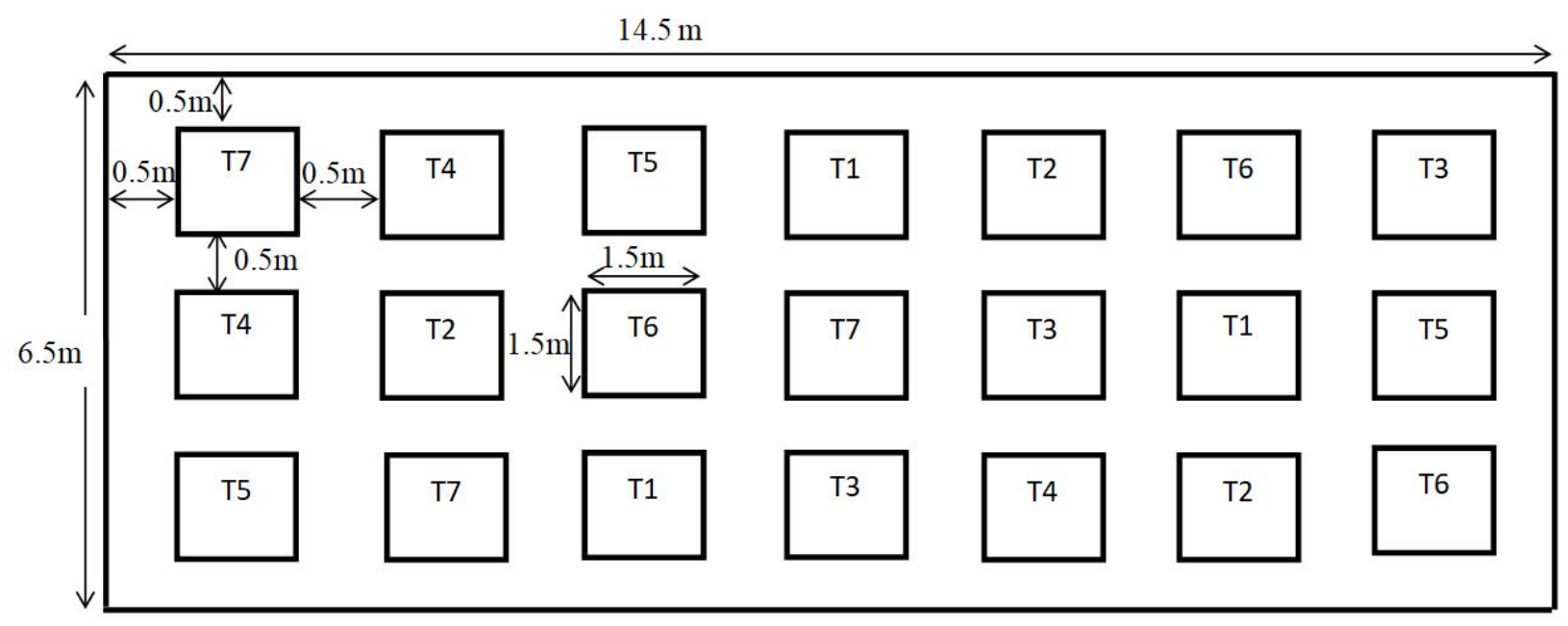

Figure 1. Layout of the research field at Tansen, Palpa

Table 1. Details about the treatments used in the field experiment

\begin{tabular}{c|llll}
\hline $\mathrm{T}$ & Trade name & \multicolumn{1}{c}{ Chemical Name } & \multicolumn{1}{c}{ Dose } & \multicolumn{1}{c}{ Type } \\
\hline T1 & Biotrine & Abamectin 0.15\% EC & $0.3 \mathrm{ml} /$ litre & Bacterial origin-contact and stomach toxicity \\
T2 & Acemepride & Imidachloprid 17.8 \% SL & $0.3 \mathrm{ml} /$ litre & Neo-nicotinoid chemical- systemic \\
T3 & Tracer & Spinosad 45\% SC & $0.3 \mathrm{ml} /$ litre & Bacterial origin-contact and ingestion toxicity \\
T4 & Neemix & Azadirachtin 300 ppm & $5 \mathrm{ml} / \mathrm{litre}$ & Neem plant origin-systemic \\
T5 & All chlora & Chlorantraniliprole 18.5\% SC & $0.3 \mathrm{ml} /$ litre & Synthetic chemical- contact and ingestion toxicity \\
T6 & Kingstar & Emamectin benzoate 5\% SC & $2 \mathrm{gm} /$ litre & Synthetic-contact and stomach toxicity \\
T7 & Control & Water spray & & \\
\hline
\end{tabular}


The observation parameters are as follows:

Percentage of leaves infested

The total number of leaves and number of infested leaves in sample plants were counted after every $6^{\text {th }}$ and $12^{\text {th }}$ day of each spray. These data were collected following non-destructive method i.e. the leaves were not picked out of the plant while counting. The percentage of leaves infested (PLI) was calculated as:

$$
\operatorname{PLI}(\%)=\frac{\mathrm{NLSP}}{\mathrm{TLSP}} \times 100
$$

NLSP : Number of infested leaves in sample plants TLSP : Total number of leaves in sample plant

\section{Percentage of fruits infested}

The total number of fruits and the number of infested fruits in sample plants were counted after every $6^{\text {th }}$ and $12^{\text {th }}$ day of each spray. These data were collected following the destructive method i.e. the fruits were picked out of the plant for counting. The percentage of fruits infested (PFI) was calculated as

$$
\operatorname{PFI}(\%)=\frac{\mathrm{NFSP}}{\mathrm{TFSP}} \times 100
$$

NFSP : Number of infested fruits in sample plants

TFSP : Total number of fruits in sample plants

\section{Average mining per leaf}

Five infested leaves from each sample plants were picked out randomly and the number of mining in each leaf was counted from which average mining per leaf (AML) was calculated.

$$
\mathrm{AML}=\frac{\mathrm{T} 1}{\mathrm{~N} 1}
$$

$\mathrm{T} 1$

: Total number of leaf minings counted in infested sample leaves of each sample plant

N1 : Number of infested leaves taken to count minings

\section{Average mining per fruit}

Five infested fruits from each sample plants were picked out randomly and the number of mining in each fruit were counted from which average mining per fruit (AMF) was calculated.

$$
\mathrm{AMF}=\frac{\mathrm{T} 2}{\mathrm{~N} 2}
$$

T2 : Total number of fruit minings counted in infested sample fruits of each sample plant

N2 : Number of infested fruits taken to count mining

\section{Average live larva per leaf}

Sample infested leaves from each sample plants were picked out randomly and the number of larva in each leaf was counted from which average larva per leaf (ALL) was calculated.

$$
\mathrm{ALL}=\frac{\mathrm{T} 3}{\mathrm{~N} 3}
$$

T3 : Total number of live larva counted in infested sample leaves of each sample plant

N3 : Number of infested leaves taken to count live larva

\section{Average live larva per fruit}

Sample infested fruits from each sample plants were picked out randomly and the number of larva in each fruit were counted from which average larva per fruit (ALF) was calculated.

$$
\mathrm{ALF}=\frac{\mathrm{T} 4}{\mathrm{~N} 4}
$$

T4 : Total number of live larva counted in 5 infested sample fruits of each sample plant

N4 : Number of infested fruits taken to count live larva

\section{Calculation of Percentage Reduction over Control (PROC)}

The mean percentage of reduced larva population due to treatments was calculated as the percentage reduction over control (PROC). (Abbott's 1925)

$$
\% \text { population reduction }=\left[1-\left(\frac{\mathrm{Ta}}{\mathrm{Tb}} \times \frac{\mathrm{Cb}}{\mathrm{Ca}}\right)\right] \times 100
$$

Where,

$\mathrm{T}_{\mathrm{a}} \quad$ : Post-treatment population in treatment

$\mathrm{T}_{\mathrm{b}} \quad$ : Pre-treatment population in treatment

$\mathrm{C}_{\mathrm{b}} \quad$ : Pre-treatment population in control

$\mathrm{C}_{\mathrm{a}} \quad$ : Post-treatment population in control

PROC helps to understand the comparative reduction of larval population by each treatment regarding population in control in terms of percentage. This, in other sense, gives the measure of comparative effectiveness of treatments.

This formula was used to calculate PROC of the larval population both in infested fruits and infested leaves. 12 day's data after the first spray was used to calculate PROC after the second spray.

\section{Statistical Analysis}

The information collected from various sources was coded, entered and analyzed using Microsoft-Excel, Statistical Package for Social Science (SPSS) version 16 and Genstat. Quantitative data were represented in tables, bar diagrams, and pie-charts. Descriptive method was used for qualitative data.

In the field-based experiment, the initially collected data were entered in MS-Excel, where data tabulation, graphs and figures were structured. Data analysis was done by using Genstat. For mean separation, Duncan multiple range test was carried out at $5 \%$ level of significance.

\section{Results and discussion}

\section{Farmer Survey}

Production Problem Ranking in Tomato

Commercial tomato farmers of Tansen, Palpa, have had many problems related to production. The major problems were insects, diseases, weather-related hazards, unavailability of inputs and lack of technical know-how. The problems were ranked based on the Likert scale. The severity index showed that the insect was the most severe problem with an index of 0.96 followed by diseases with an index of 0.78 . Weather-related hazard was the third most severe problem with an index of 0.53 . Similarly, lack of technical know-how and unavailability of inputs was found as the fourth and the fifth problem with an index of 0.39 and 0.35 respectively (Table 2 ). 
Table 2. Problem ranking in tomato production in Tansen, Palpa, 2018

\begin{tabular}{|c|c|c|c|c|c|c|c|c|c|}
\hline \multirow{2}{*}{ Problems } & \multicolumn{5}{|c|}{ Level of problem } & \multirow{2}{*}{ Total } & \multirow{2}{*}{ Weight } & \multirow{2}{*}{ Index } & \multirow{2}{*}{ Rank } \\
\hline & 1 & 0.8 & 0.6 & 0.4 & 0.2 & & & & \\
\hline Insect & 25 & 4 & 1 & 0 & 0 & 30 & 28.8 & 0.96 & I \\
\hline Disease & 3 & 22 & 4 & 1 & 0 & 30 & 23.4 & 0.78 & II \\
\hline Weather-related hazards & 1 & 2 & 14 & 11 & 2 & 30 & 15.8 & 0.53 & III \\
\hline Unavailability of inputs & 1 & 0 & 4 & 10 & 15 & 30 & 10.4 & 0.35 & $\mathrm{~V}$ \\
\hline Lack of technical know-how & 0 & 2 & 7 & 8 & 13 & 30 & 11.6 & 0.39 & IV \\
\hline
\end{tabular}

Table 3. Insect pest severity ranking in tomato production in Tansen, Palpa, 2018

\begin{tabular}{|c|c|c|c|c|c|c|c|c|c|}
\hline \multirow{2}{*}{ Problems } & \multicolumn{5}{|c|}{ Level of problem } & \multirow{2}{*}{ Total } & \multirow{2}{*}{ Weight } & \multirow{2}{*}{ Index } & \multirow{2}{*}{ Rank } \\
\hline & 1 & 0.8 & 0.6 & 0.4 & 0.2 & & & & \\
\hline Tomato Leaf Miner & 15 & 11 & 4 & 0 & 0 & 30 & 26.2 & 0.87 & I \\
\hline Tomato Fruit Borer & 9 & 13 & 7 & 1 & 0 & 30 & 24 & 0.80 & II \\
\hline Cutworm & 6 & 6 & 11 & 5 & 2 & 30 & 19.8 & 0.66 & III \\
\hline Aphids & 0 & 0 & 4 & 10 & 16 & 30 & 9.6 & 0.32 & $\mathrm{~V}$ \\
\hline Whitefly & 0 & 0 & 4 & 14 & 12 & 30 & 10.4 & 0.35 & IV \\
\hline
\end{tabular}

Table 4. Disease severity ranking in tomato production in Tansen, Palpa, 2018

\begin{tabular}{l|ccccccccc}
\hline \multirow{2}{*}{\multicolumn{1}{c|}{ Problems }} & \multicolumn{4}{c}{ Level of problem } & \multirow{2}{*}{ Total } & Weight & Index & \multirow{2}{*}{ Rank } \\
\cline { 2 - 5 } & 1 & 0.75 & 0.5 & 0.25 & & & \\
\hline Late Blight & 28 & 2 & 0 & 0 & 30 & 29.5 & 0.98 & I \\
Tomato wilt & 1 & 15 & 13 & 1 & 30 & 19 & 0.63 & II \\
Damping-off & 1 & 13 & 6 & 10 & 30 & 16.25 & 0.54 & III \\
Viral Diseases & 0 & 0 & 11 & 19 & 30 & 10.25 & 0.34 & V \\
\hline
\end{tabular}

Insect Pest Severity Ranking in Tomato Production

The major insects infesting the tomato crop was tomato leaf miner ( $T$. absoluta) with an index value of 0.87 . Similarly, tomato fruit borer was found the second most severe insect with an index value of 0.80 while the cutworm was third most severe insect with an index value of 0.66. Similarly, whitefly and aphids were found the least severe insects with an index of 0.35 and 0.32 respectively. The result aligns with those obtained from the focused group discussion with commercial tomato growers of the region (Table 3).

Diseases Severity Ranking in Tomato Production

The severity index showed that among diseases, late blight was the most severely affecting the profitability of tomato with an index of 0.98 . Tomato Wilt was found to be the second most severe diseases with an index value of 0.63. Similarly, damping off and viral diseases was found least severe with an index of 0.54 and 0.34 respectively (Table 4).

Ranking of Tuta absoluta out of many other Problems

Tuta absoluta was found to be the most problematic among all the problems as reported by $60 \%$ of the respondents. Similarly, $23.33 \%$ farmer's insight that the Tuta absoluta was as problematic as Helicoverpa armigera and Late blight disease (Phytophthora infestans) while only $6.67 \%$ and $3.33 \%$ farmers reported it to be fewer problematic and least problematic of all in tomato production than other problems (Figure 2). A similar result was obtained from other infested districts as T. absoluta was found to be most serious among all other problems of tomato production (Bajracharya et al., 2016).

Management Practices Followed by Farmers for $T$. absoluta

The farmers of Tansen, Palpa have been practising different methods like cultural, physical, mechanical and chemical for control of Tuta absoluta in the field condition.
It was found that chemical insecticides (99\%) were the most frequented management practices. It was followed by pheromone traps (72\%), botanical insecticides (69\%), cultural methods (64\%), mechanical methods (42\%) and physical methods (21\%) (Figure 3).

The higher use of chemical insecticides was due to better control and easy to use than other methods. Moreover, the use of pheromone traps and botanical insecticides like azadirachtin was due to subsidy provided by PMAMP, Vegetable zone, Palpa to the farmers.

A similar result was reported by (Sah, 2017) in Kavre district, where 89 percent of respondent used chemical pesticide. Maximum use of chemical pesticide was related to its effectiveness and ease of use. It also reported that the pheromone traps may be effective in controlling $T$. absoluta even in an intense infestation.

Major Insecticides Used by Farmers

It was found that $86.67 \%$ of farmers used Emamectin benzoate, $63.33 \%$ used Imidachloprid, $46.67 \%$ used Azadirachtin (Neem based insecticides), $33.33 \%$ farmers used abamectin and $26.67 \%$ used dichlorovus (Figure 4).

The higher use of emamectin benzoate was due to better crop protection. Moreover, comparative higher use of imidachloprid was reported due to local availability and promotion about its effectiveness from agro-vets. The use of Azadirachtin and Abamectin was increasing due to promotion by PMAMP, PIU, Vegetable zone, Palpa.

\section{Field Experiment}

The tomato plants in the research field were found to be infested with Tuta absoluta during the onset of research. Per-spray data were collected and treatments were applied twice at 12 days interval. Observations were made on $6^{\text {th }}$ and $12^{\text {th }}$ days after each spray. The results of the experiment were analyzed and presented with figures and 
tables where necessary.

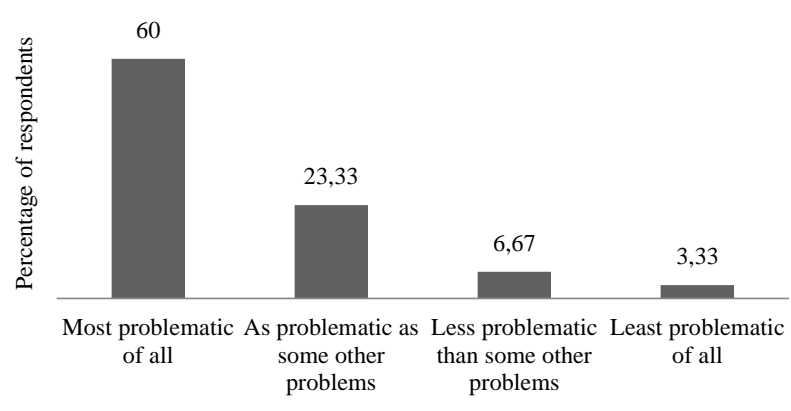

Figure 2. Ranking of Tuta absoluta out of other problems of tomato production in Palpa, 2018

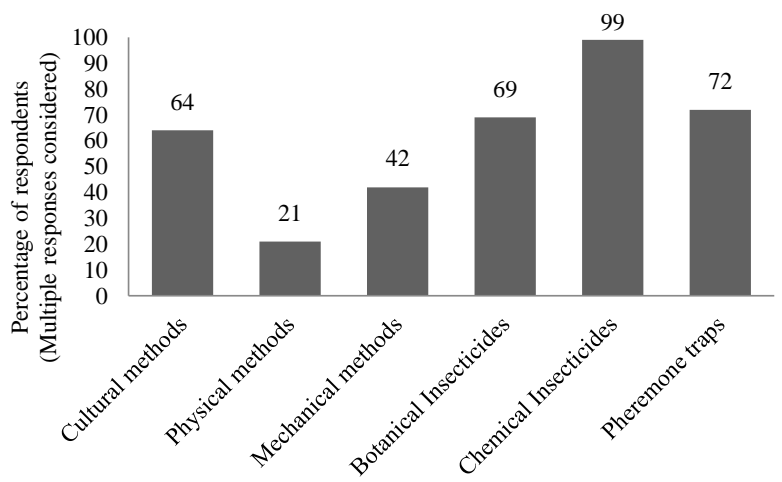

Figure 3. Management practices followed by tomato farmers to control Tuta absoluta in Palpa, 2018

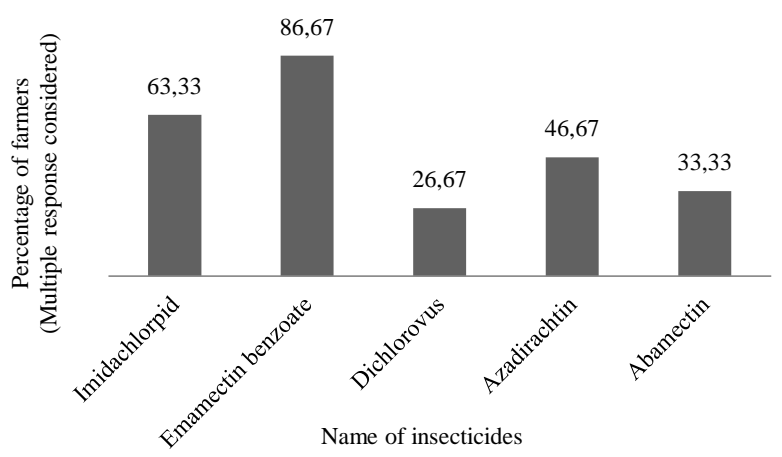

Figure 4. Chemical insecticides used by farmers for Tuta absoluta management in Tansen, Palpa, 2018

Table 5. Percentage of infected leaves on different days after spray at Tansen, Palpa, 2018

\begin{tabular}{l|cccc}
\hline \multirow{2}{*}{\multicolumn{1}{c}{ Treatment }} & \multicolumn{4}{c}{ Percentage of infected leaves } \\
\cline { 2 - 5 } & \multicolumn{3}{|c}{ First Spray } & \multicolumn{3}{c}{ Second Spray } \\
\cline { 2 - 5 } & 6 DAS & 12 DAS & 6 DAS & 12 DAS \\
\hline Abamectin & $27.26^{\mathrm{bc}}$ & $29.68^{\mathrm{bc}}$ & $28.72^{\mathrm{b}}$ & $32.84^{\mathrm{b}}$ \\
Imidachloprid & $29.98^{\mathrm{c}}$ & $33.41^{\mathrm{c}}$ & $33.89^{\mathrm{b}}$ & $34.73^{\mathrm{b}}$ \\
Spinosad & $17.77^{\mathrm{a}}$ & $18.35^{\mathrm{a}}$ & $18.73^{\mathrm{a}}$ & $17.41^{\mathrm{a}}$ \\
Azadirachtin & $29.79^{\mathrm{c}}$ & $33.99^{\mathrm{c}}$ & $31.94^{\mathrm{b}}$ & $35.79^{\mathrm{b}}$ \\
Chlorantraniliprole & $19.19^{\mathrm{a}}$ & $20.22^{\mathrm{a}}$ & $19.76^{\mathrm{a}}$ & $18.93^{\mathrm{a}}$ \\
Emamectin benzoate & $21.14^{\mathrm{ab}}$ & $25.23^{\mathrm{ab}}$ & $27.21^{\mathrm{b}}$ & $29.95^{\mathrm{b}}$ \\
Control & $34.36^{\mathrm{c}}$ & $37.71^{\mathrm{c}}$ & $41.65^{\mathrm{c}}$ & $45.71^{\mathrm{c}}$ \\
Grand Mean & $25.64^{\mathrm{c}}$ & 28.37 & 28.84 & 30.77 \\
SEM( \pm$)$ & 2.260 & 2.535 & 2.403 & 2.225 \\
LSD $(0.05)$ & $6.962^{* * *}$ & $7.810^{* * *}$ & $7.403^{* * *}$ & $6.855^{* * *}$ \\
CV $(\%)$ & 15.3 & 15.5 & 14.4 & 12.5 \\
\hline Not & &
\end{tabular}

Note: Same letter with the means do not differ significantly at $\mathrm{P}=0.05$ by DMRT, SEM: Standard error of mean, CV: Coefficient of variation, LSD Least significant difference, $* * *: 0.1 \%$ level of significance, DAS: Days after spray

\section{Percentage of leaves and fruits infested}

At 6DAS of the first spray, the least infested leaves were found in spinosad $(17.77 \%)$ which was statistically similar to chlorantraniliprole $(19.19 \%)$ and emamectin benzoate $(21.14 \%)$. Similarly, the highest infested leaves were found in control (34.36\%) which was statistically similar to that of imidachloprid (29.98\%), azadirachtin $(29.79 \%)$ and abamectin $(27.26 \%)$. Similar results were obtained at 12 DAS of the first spray with the least infested leaves found in spinosad $(18.35 \%)$ and highest infested leaves found in control (37.71\%) (Table 5).

At 6 days after the second spray, the least infested leaves were found in spinosad $(18.73 \%)$ which was at par with chlorantraniliprole $(19.76 \%)$. Similarly, the highest leaves damage was found in control $(41.65 \%)$. Similar results were obtained at 12 days after the second spray with lowest infestation found in spinosad (17.41) and chlorantraniliprole (187.93) and highest infestation found in control (45.71) (Table 5).

At 6 days after the first spray, the lowest percentage of fruits infested was found in spinosad (5.622) which was statistically at par with emamectin benzoate (6.008), imidachloprid (8.493) and chlorantraniliprole (8.588). The highest percentage of infested fruits was found in control (14.934) and azadirachtin (13.263) and they were found statistically similar (Table 6).

At 12 days after the first spray, similar results were obtained with the lowest fruit infestation found in spinosad (1.793), which was statistically at par with chlorantraniliprole (2.220). Highest fruit infestation was found in control (7.306) (Table 6).

At 6 days after the second spray, the lowest infestation of fruits was found in chlorantraniliprole (0.575), which was statistically at par with spinosad (0.592). The highest infestation of fruits was found in control (9.149) (Table 6).

At 12 days after the second spray, the lowest infestation of fruits was found in chlorantraniliprole $(0.133)$ followed by spinosad (0.181) and emamectin benzoate (0.918), which were also found to be significantly similar. Highest fruits infestation was found in control (8.865) (Table 6).

From the results above, it is clear that chlorantraniliprole and spinosad were found most effective for reducing the leaf and fruit damage due to Tuta absoluta in the farmer's field condition. Also, all the treatment gave better results than control.

The results for leaves and fruits damage are following the findings of Bajracharya et al. (2016), who reported that chlorantraniliprole and spinosad were effective for reducing damage and achieving higher larval population control in field condition. Fruits

Average Larval Population Per Infested Leaves and

The result shows that the average live larval population per infested leaves was found to be highly influenced by the application of treatments at all days after spray.

At 6 days after the first spray, the lowest larval population on leaves was found in chlorantraniliprole (0.1573) which was statistically at par with spinosad (0.2526) and the highest larval population was found in control (0.6823). Similar results were found at 12 days after the first spray, with lowest larval population obtained in chlorantraniliprole (0.0881) followed by spinosad (0.0889) which were also statistically similar. The highest larval population was found in control (0.7486) (Table 7). 
Table 6. Percentage of infested fruits at different days after spray at Tansen, Palpa, 2018

\begin{tabular}{l|cccc}
\hline \multirow{2}{*}{\multicolumn{1}{c|}{ Treatment }} & \multicolumn{4}{c}{ Percentage of infested fruits } \\
\cline { 2 - 5 } & \multicolumn{3}{|c}{ First Spray } & \multicolumn{3}{c}{ Second Spray } \\
\cline { 2 - 5 } & $6 \mathrm{DAS}$ & $12 \mathrm{DAS}$ & $6 \mathrm{DAS}$ & $12 \mathrm{DAS}$ \\
\hline Abamectin & $11.113^{\mathrm{bc}}$ & $4.435^{\mathrm{bc}}$ & $2.024^{\mathrm{b}}$ & $1.988^{\mathrm{c}}$ \\
Imidachloprid & $8.493^{\mathrm{ab}}$ & $3.581^{\mathrm{b}}$ & $2.695^{\mathrm{b}}$ & $1.267^{\mathrm{bc}}$ \\
Spinosad & $5.622^{\mathrm{a}}$ & $1.793^{\mathrm{a}}$ & $0.592^{\mathrm{a}}$ & $0.181^{\mathrm{a}}$ \\
Azadirachtin & $13.263^{\mathrm{cd}}$ & $5.335^{\mathrm{c}}$ & $3.787^{\mathrm{c}}$ & $1.510^{\mathrm{bc}}$ \\
Chlorantraniliprole & $8.588^{\mathrm{ab}}$ & $2.220^{\mathrm{a}}$ & $0.575^{\mathrm{a}}$ & $0.133^{\mathrm{a}}$ \\
Emamectin benzoate & $6.008^{\mathrm{a}}$ & $3.487^{\mathrm{b}}$ & $2.292^{\mathrm{b}}$ & $0.918^{\mathrm{ab}}$ \\
Control & $14.934^{\mathrm{d}}$ & $7.306^{\mathrm{d}}$ & $9.149^{\mathrm{d}}$ & $8.865^{\mathrm{d}}$ \\
Grand Mean & 9.72 & 4.02 & 3.02 & 2.12 \\
SEM( $( \pm)$ & 0.950 & 0.377 & 0.306 & 0.288 \\
LSD (0.05) & $2.928^{* * *}$ & $1.163^{* * *}$ & $0.942^{* * *}$ & $0.887^{* * *}$ \\
CV $(\%)$ & 16.9 & 16.3 & 17.6 & 23.5 \\
\hline
\end{tabular}

Note: Same letter with the means do not differ significantly at $\mathrm{P}=0.05$ by DMRT, SEM: Standard error of mean, CV: Coefficient of variation, LSD: Least significant difference, $* * *: 0.1 \%$ level of significance

Table 7. Average live larva per infested leaf at different days after spray at Tansen, Palpa, 2018

\begin{tabular}{l|cccc}
\hline \multirow{2}{*}{\multicolumn{1}{c|}{ Treatment }} & \multicolumn{4}{|c}{ Average larva per infested leaf } \\
\cline { 2 - 5 } & \multicolumn{3}{|c}{ First Spray } & \multicolumn{2}{c}{ Second Spray } \\
\cline { 2 - 5 } & 6 DAS & $12 \mathrm{DAS}$ & $6 \mathrm{DAS}$ & $12 \mathrm{DAS}$ \\
\hline Abamectin & $0.3205^{\mathrm{b}}$ & $0.1746^{\mathrm{b}}$ & $0.1503^{\mathrm{bc}}$ & $0.0723^{\mathrm{ab}}$ \\
Imidachloprid & $0.5405^{\mathrm{c}}$ & $0.1687^{\mathrm{b}}$ & $0.1063^{\mathrm{ab}}$ & $0.0734^{\mathrm{ab}}$ \\
Spinosad & $0.2526^{\mathrm{ab}}$ & $0.0889^{\mathrm{a}}$ & $0.0457^{\mathrm{a}}$ & $0.0145^{\mathrm{ab}}$ \\
Azadirachtin & $0.3153^{\mathrm{b}}$ & $0.2735^{\mathrm{c}}$ & $0.2143^{\mathrm{c}}$ & $0.0758^{\mathrm{b}}$ \\
Chlorantraniliprole & $0.1573^{\mathrm{a}}$ & $0.0881^{\mathrm{a}}$ & $0.0390^{\mathrm{a}}$ & $0.0116^{\mathrm{a}}$ \\
Emamectin benzoate & $0.3059^{\mathrm{b}}$ & $0.1711^{\mathrm{b}}$ & $0.1052^{\mathrm{ab}}$ & $0.0393^{\mathrm{ab}}$ \\
Control & $0.6823^{\mathrm{d}}$ & $0.7486^{\mathrm{d}}$ & $0.7950^{\mathrm{d}}$ & $0.8723^{\mathrm{c}}$ \\
Grand Mean & 0.368 & 0.2448 & 0.2080 & 0.1656 \\
SEM $( \pm)$ & 0.0426 & 0.01826 & 0.02318 & 0.01875 \\
LSD $(0.05)$ & $0.1313^{* * *} 0.05627^{* *}$ & $0.07141^{* * *}$ & $0.05778^{* * *}$ \\
CV $(\%)$ & 20.1 & 12.9 & 19.3 & 19.6 \\
\hline
\end{tabular}

Note: Same letter with the means do not differ significantly at $\mathrm{P}=0.05$ by DMRT, SEM: Standard error of mean, CV: Coefficient of variation, LSD: Least significant difference, $* * *: 0.1 \%$ level of significance

Table 8. Average live larva per infested fruit at different days after spray at Tansen, Palpa, 2018

\begin{tabular}{l|cccc}
\hline \multirow{2}{*}{\multicolumn{1}{c}{ Treatment }} & \multicolumn{4}{|c}{ Average larva per infested fruit } \\
\cline { 2 - 5 } & \multicolumn{3}{|c}{ First Spray } & \multicolumn{2}{c}{ Second Spray } \\
\cline { 2 - 5 } & 6 DAS & 12 DAS & 6 DAS & 12 DAS \\
\hline Abamectin & $0.9811^{\mathrm{b}}$ & $0.9226^{\mathrm{ab}}$ & $0.8651^{\mathrm{b}}$ & $0.7589^{\mathrm{bc}}$ \\
Imidachloprid & $1.0540^{\mathrm{b}}$ & $0.9578^{\mathrm{ab}}$ & $0.8370^{\mathrm{b}}$ & $0.7440^{\mathrm{bc}}$ \\
Spinosad & $0.7761^{\mathrm{a}}$ & $0.6111^{\mathrm{a}}$ & $0.4736^{\mathrm{a}}$ & $0.3333^{\mathrm{ab}}$ \\
Azadirachtin & $0.9930^{\mathrm{b}}$ & $0.9264^{\mathrm{ab}}$ & $0.8450^{\mathrm{b}}$ & $0.8029^{\mathrm{c}}$ \\
Chlorantraniliprole & $0.7867^{\mathrm{a}}$ & $0.5958^{\mathrm{a}}$ & $0.3333^{\mathrm{a}}$ & $0.2893^{\mathrm{a}}$ \\
Emamectin benzoate & $0.9474^{\mathrm{ab}}$ & $0.7460^{\mathrm{a}}$ & $0.4444^{\mathrm{a}}$ & $0.3889^{\mathrm{abc}}$ \\
Control & $1.0966^{\mathrm{b}}$ & $1.1868^{\mathrm{b}}$ & $1.2803^{\mathrm{c}}$ & $1.4562^{\mathrm{d}}$ \\
Grand Mean & 0.948 & 0.849 & 0.726 & 0.682 \\
SEM( $( \pm)$ & 0.0549 & 0.1175 & 0.0926 & 0.1364 \\
LSD $(0.05)$ & $0.1691^{* *}$ & $0.3620^{* *}$ & $0.2852^{* *}$ & $0.4203^{* * *}$ \\
CV $(\%)$ & 10.0 & 24.0 & 22.1 & 34.6 \\
\hline
\end{tabular}

Note: Same letter with the means do not differ significantly at $\mathrm{P}=0.05$ by DMRT, SEM: Standard error of mean, CV: Coefficient of variation, LSD Least significant difference, ${ }^{* * *}: 0.1 \%$ level of significance

At 6 days after the second spray, the lowest larval population on leaves was found in chlorantraniliprole (0.0390) which was statistically at par with spinosad (0.0457) and emamectin benzoate $(0.1052)$ with a highest larval population per leaves found in control (0.7950). At 12 days after the second spray, the highest larval population was found in control (0.8723). The lowest larval population was found in chlorantraniliprole (0.0116) which was statistically similar to spinosad $(0.0145)$, emamectin benzoate (0.0393), abamectin (0.0723) and imidachloprid (0.0734) (Table 7).

The result shows that the average live larval population counted in infested fruits was found to be highly influenced by the application of treatments at all days after spray.

It was found that at 6 days after the first spray, the lowest larval population per infested fruit was found in spinosad (0.7761) which was statistically at par with chlorantraniliprole (0.7867) and emamectin benzoate (0.9474). Similarly, the highest larval population count was obtained in control (1.0966) which was also statistically similar with imidachloprid (1.0540), azadirachtin (0.9930) and abamectin (0.9811) (Table 8)

Similarly, on $12^{\text {th }}$ day after the first spray, lowest larval count per infested fruit was obtained in chlorantraniliprole (0.5958), which was found statistically at par with all other treatments except control, which has a highest larval count (1.1868) (Table 8).

At 6 days after the second spray, the larval population was found to be lowest in chlorantraniliprole $(0.333)$ which was statistically at par with emamectin benzoate $(0.4444)$ and spinosad (0.4736). The highest larval population was found in control (1.2803). A similar result was obtained in 12days after the second spray, where chlorantraniliprole, spinosad and emamectin benzoate had a least larval population in fruits respectively while the control had the highest larval population (Table 8).

Above results were evident that chlorantraniliprole was most effective for reducing the larval population in both leaves and fruits. Spinosad and emamectin benzoate was also found to be similarly effective. According to Deleva and Harizanova (2014), azadirachtin, emamectin benzoate, spinosad and chlorantraniliprole caused $90-100 \%$ mortality in lab condition, which is following the findings of this study. The effectiveness of chlorantraniliprole against Tuta absoluta was due to its fastest action on feeding cessation and reduction in feeding damage. Bassi et al. (2009) reported that chlorantraniliprole was effective in stopping the feeding of the larva in a short time (few minutes to few hours) after ingestion. fruits

Average number of mining per infested leaves and

The application of treatments had no significant effect on the number of mining in infected leaves as well as fruits at any days after spray (Table 9, Table 10). Although the number of mining was directly associated with the larval population, despite the reduction of larval population by the use of chemical insecticides, there was the nonsignificant difference in the mining. This was due to the application of treatments after the field was already infested by Tuta absoluta as the empty mines created by the dead larva exist in the plant parts. This result was supported by the findings from Sallam et al. (2015), who reported that the post-infestation application of chemical insecticides didn't had a significant effect on mining percent reduction, due to presence of already created empty mines by the dead larva.

Population reduction over control (PROC) of larva in leaves and fruits

All the insecticides were able to reduce the population of larva in leaves after each spray (Table 11). The population reduction for the first spray was based on prespray data and the second spray was based on data observed in 12 days after the first spray. 
At 6 days after the first spray, highest population reduction percentage was obtained in chlorantraniliprole $(81.10 \%)$, followed by spinosad $(62.83 \%)$ and abamectin $(55.48 \%)$ while lowest reduction percentage was found in Imidachloprid (28.25\%) and azadirachtin $(46.75 \%)$ (Table 11$)$.

At 12 days after the first spray, there was a greater reduction of larval population in all the treatments as compared to the previous day of observation. Highest population reduction was observed in chorantraniliprole $(88.95 \%)$, followed by spinosad $(88.08 \%)$ and emamectin benzoate $(75.78 \%)$. Lowest population reduction was observed in azadirachtin (57.90\%) (Table 11).

At 6 days after the second spray, it was found that highest population reduction was in spinosad $(58.71 \%)$ and chlorantraniliprole $(58.33 \%)$ followed by emamectin benzoate $(41.45 \%)$ and the lowest reduction was observed in azadirachtin $(26.23 \%)$. Similarly, at 12 days after the second spray, highest population reduction was observed in chlorantraniliprole $(88.70 \%)$ and spinosad $(86.01 \%)$ followed by emamectin benzoate $(80.30 \%)$. Similarly, the lowest reduction percentage was observed in imidachloprid $(64.11 \%)$ and abamectin $(64.46 \%)$ (Table 11$)$.

All the treatments were able to reduce the larval population of fruit after every spray.

Chlorantraniliprole was found continuously superior at reducing the larval population at each day of observation with $30.65 \%$ and $51.47 \%$ reduction observed at 6 and 12 days after the first spray. Similarly, $48.14 \%$ and $60.43 \%$ reduction was observed in 6 and 12 days after the second spray. Similarly, emamectin benzoate was found to be in second place, with a reduced rate of $18.30 \%$ and $40.56 \%$ at 6 and 12 days after the first spray. Likewise, $44.77 \%$ and $57.51 \%$ reduction was observed in 6 and 12 days after the second spray (Table 12).

Ayalew (2011) reported that chlorantraniliprole was most effective against $T$. absoluta due to its diamide ingredient which acts by modulating the ryanodine receptor. Insecticides with this mode of action were reported to had better efficacy against leaf miners due to their capabilities of reaching mining larva inside leaf by penetrating leaf surface.

Table 9. Average mining per infested leaf at different days Table 10. Average mining per infested fruit at different days after spray at Tansen, Palpa, 2018

\begin{tabular}{|c|c|c|c|c|c|c|c|c|c|}
\hline \multirow{3}{*}{ Treatments } & \multicolumn{4}{|c|}{ Average mining per infested leaf } & \multirow{3}{*}{ Treatments } & \multicolumn{4}{|c|}{ Average mining per infested fruit } \\
\hline & \multicolumn{2}{|c|}{ First Spray } & \multicolumn{2}{|c|}{ Second Spray } & & \multicolumn{2}{|c|}{ First Spray } & \multicolumn{2}{|c|}{ Second Spray } \\
\hline & 6 DAS & 12 DAS & 6 DAS & 12 DAS & & 6 DAS & 12 DAS & 6 DAS & 12 DAS \\
\hline Abamectin & 1.279 & 1.331 & 1.415 & 1.419 & Abamectin & 1.394 & 1.311 & 1.333 & 1.167 \\
\hline Imidachloropid & 2.147 & 2.033 & 1.918 & 1.941 & Imidachloprid & 1.375 & 1.306 & 1.550 & 1.083 \\
\hline Spinosad & 1.612 & 1.430 & 1.371 & 1.458 & Spinosad & 1.381 & 1.222 & 0.667 & 0.333 \\
\hline Azadirachtin & 1.470 & 1.413 & 1.581 & 1.451 & Azadirachtin & 1.107 & 1.267 & 1.444 & 2.167 \\
\hline Chlorantraniliprole & 1.297 & 1.385 & 1.387 & 1.409 & Chlorantraniliprole & 1.176 & 1.000 & 1.000 & 0.333 \\
\hline Emamectin benzoate & 1.330 & 1.308 & 1.340 & 1.234 & Emamectin benzoate & 1.056 & 1.333 & 1.333 & 1.333 \\
\hline Control & 1.712 & 1.721 & 1.642 & 1.653 & Control & 1.278 & 1.250 & 1.078 & 1.461 \\
\hline Grand Mean & 1.550 & 1.517 & 1.522 & 1.509 & Grand Mean & 1.252 & 1.241 & 1.201 & 1.13 \\
\hline F-test & NS & NS & NS & NS & F value & NS & NS & NS & NS \\
\hline
\end{tabular}

Note: Same letter with the means do not differ significantly at P=0.05 by DMRT, SEM: Standard error of mean, CV: Coefficient of variation, LSD:

Least significant difference, NS: Non-significant, DAS: Days after spray

Table 11. Population reduction percentage of larva in infested leaves over control

\begin{tabular}{|c|c|c|c|c|c|c|c|c|c|}
\hline \multirow{4}{*}{ Treatment } & \multirow{4}{*}{$\begin{array}{c}\text { Pre-Spray } \\
\text { Avg. } \\
\text { Popln } \\
\end{array}$} & \multicolumn{8}{|c|}{ PROC of larva found in leaves } \\
\hline & & \multicolumn{4}{|c|}{ First Spray } & \multicolumn{4}{|c|}{ Second Spray } \\
\hline & & \multicolumn{2}{|c|}{$6 \mathrm{DAS}$} & \multicolumn{2}{|c|}{$12 \mathrm{DAS}$} & \multicolumn{2}{|c|}{6 DAS } & \multicolumn{2}{|c|}{12 DAS } \\
\hline & & $\begin{array}{l}\text { Avg. } \\
\text { Popln }\end{array}$ & $\begin{array}{c}\text { PROC } \\
\%\end{array}$ & $\begin{array}{l}\text { Avg. } \\
\text { Popln }\end{array}$ & $\begin{array}{c}\text { PROC } \\
\%\end{array}$ & $\begin{array}{l}\text { Avg. } \\
\text { Popln }\end{array}$ & $\begin{array}{c}\text { PROC } \\
\%\end{array}$ & $\begin{array}{l}\text { Avg. } \\
\text { Popln }\end{array}$ & $\begin{array}{c}\text { PROC } \\
\%\end{array}$ \\
\hline Abamectin & 1.839 & 0.952 & 55.48 & 0.524 & 77.67 & 0.451 & 18.92 & 0.217 & 64.46 \\
\hline Imidachloprid & 1.944 & 1.622 & 28.25 & 0.526 & 78.78 & 0.319 & 42.92 & 0.220 & 64.11 \\
\hline Spinosad & 1.754 & 0.758 & 62.83 & 0.267 & 88.08 & 0.117 & 58.71 & 0.043 & 86.01 \\
\hline Azadirachtin & 1.528 & 0.946 & 46.75 & 0.821 & 57.90 & 0.643 & 26.23 & 0.228 & 76.21 \\
\hline Chlorantraniliprole & 1.876 & 0.412 & 81.10 & 0.264 & 88.95 & 0.117 & 58.33 & 0.035 & 88.70 \\
\hline Emamectin benzoate & 1.661 & 0.928 & 51.96 & 0.513 & 75.78 & 0.319 & 41.45 & 0.118 & 80.30 \\
\hline Control & 1.761 & 2.047 & 0 & 2.246 & 0 & 2.385 & 0 & 2.617 & 0 \\
\hline
\end{tabular}

Note: Avg: Average, Popln: Population, DAS: Days after Spray, PROC: Population reduction over control

Table 12. Population reduction percentage of larva in infested fruits over control

\begin{tabular}{|c|c|c|c|c|c|c|c|c|c|}
\hline \multirow{4}{*}{ Treatment } & \multirow{4}{*}{$\begin{array}{c}\text { Pre-Spray } \\
\text { Avg. } \\
\text { Popln }\end{array}$} & \multicolumn{8}{|c|}{ PROC of larva found in fruits } \\
\hline & & \multicolumn{4}{|c|}{ First Spray } & \multicolumn{4}{|c|}{ Second Spray } \\
\hline & & \multicolumn{2}{|c|}{$6 \mathrm{DAS}$} & \multicolumn{2}{|c|}{12 DAS } & \multicolumn{2}{|c|}{6 DAS } & \multicolumn{2}{|c|}{$12 \mathrm{DAS}$} \\
\hline & & $\begin{array}{l}\text { Avg. } \\
\text { Popln }\end{array}$ & $\begin{array}{c}\text { PROC } \\
\%\end{array}$ & $\begin{array}{l}\text { Avg. } \\
\text { Popln }\end{array}$ & $\begin{array}{c}\text { PROC } \\
\%\end{array}$ & $\begin{array}{l}\text { Avg. } \\
\text { Popln }\end{array}$ & $\begin{array}{c}\text { PROC } \\
\%\end{array}$ & $\begin{array}{l}\text { Avg. } \\
\text { Popln }\end{array}$ & $\begin{array}{c}\text { PROC } \\
\%\end{array}$ \\
\hline Abamectin & 3.007 & 2.943 & 13.72 & 2.768 & 25.04 & 2.595 & 13.07 & 2.277 & 32.96 \\
\hline Imidachloropid & 3.250 & 3.162 & 14.23 & 2.873 & 27.99 & 2.511 & 18.99 & 2.232 & 36.69 \\
\hline Spinosad & 2.429 & 2.328 & 15.49 & 1.833 & 38.51 & 1.421 & 28.16 & 1.000 & 55.54 \\
\hline Azadirachtin & 3.000 & 2.979 & 12.46 & 2.779 & 24.55 & 2.535 & 15.45 & 2.409 & 29.36 \\
\hline Chlorantraniliprole & 3.000 & 2.360 & 30.65 & 1.787 & 51.47 & 1.000 & 48.14 & 0.868 & 60.43 \\
\hline Emamectin benzoate & 3.067 & 2.842 & 18.30 & 2.238 & 40.56 & 1.333 & 44.77 & 1.167 & 57.51 \\
\hline Control & 2.900 & 3.290 & 0 & 3.561 & 0 & 3.841 & 0 & 4.369 & 0 \\
\hline
\end{tabular}

Note: Avg: Average, Popln: Population, DAS: Days after Spray, PROC: Population reduction over control 


\section{Conclusion}

The Tuta absoluta was the major production problem of tomato farming in Tansen, Palpa and chemical insecticides are the most preferred control measures at field condition due to their superior performance and easiness to use. Among the insecticides used for the field experiment, chlorantraniliprole was found to be most effective for reducing larval population and its damage in leaves and fruits followed by spinosad and emamectin benzoate.

\section{Acknowledgement}

The authors would like to thank Prime Minister Agriculture Modernization Project, Project Implementation Unit, Vegetable Zone, Palpa for providing constant support and guidance during the research period.

\section{Funding}

This study was financially supported by Agriculture and Forestry University, Rampur, Chitwan, Nepal.

\section{Conflict of Interest}

The authors declare that there is no conflict of interest regarding the publication of this article.

\section{References}

Abdul-Ridha M, Alwan S, Helal, SA. 2012. Alternative Hosts of South American Tomato Moth Tuta absoluta (Gelechiidae: Lepidoptera) in Some Tomato Farms of Najaf Province. Euphrates Journal of Agriculture Sciences, 4(4): 130-137.

Arnó J, Gabarra R. 2010. Controlling Tuta absoluta, A New Invasive Pest in Europe. IRTA Cabrils, Spain: European Network for the Durable Exploitation.

Ayalew G. 2011. Effect of the Insect Growth Regulator Novaluron on Diamondback Moth, Plutella xylostella L. (Lepidoptera: Plutellidae), and its Indigenous Parasitoids. Crop Protection, 30(8): 1087-1090. https://doi.org/10.1016/ j.cropro.2011.03.027

Bajracharya ASR, Mainali RP, Bhat BV, Bista S, Shashank PR, Meshram NM. 2016. The first record of South The first record South American tomato leaf miner, Tuta absoluta (Meyrick 1917) (Lepidoptera: Gelechiidae) in Nepal. Journal of Entomology and Zoology Studies, 4(4): 1359-1363.

Bassi A, Rison JL, Wiles, JA. 2009. Chlorantraniliprole (DPXE2Y45, Rynaxypyr ${ }^{\circledR}$, Coragen $\left.\AA\right)$, A New Diamide Insecticide for Control of Codling Moth (Cydia pomonella), Colorado Potato Beetle (Leptinotarsa decemlineata) and European Grapevine Moth (Lobesia botrana). Proceedings of the 9th Slovenian Conference on Plant Protection with International Participation: 39-45.

Chidege M, Al-zaidi S, Hassan N, Julie A, Kaaya E, Mrogoro S. 2016. First Record of Tomato Leaf Miner Tuta absoluta (Meyrick) (Lepidoptera: Gelechiidae) in Tanzania. Agriculture \& Food Security 5, 17(2016) https://doi.org/ 10.1186/s40066-016-0066-4

Deleva EA, Harizanova VB. 2014. Efficacy Evaluation of Insecticides on Larvae of the Tomato Borer Tuta absoluta, Meyrick (Lepidoptera: Gelechiidae) under laboratory conditions. Journal of International Scientific Publications: Agriculture and Food, 2: 158-164.

Estay P. 2000. Polilla del tomate Tuta absoluta (Meyrick). Impresos CGS Ltda.
FAO. 2012. Growing Greener cities in Africa. Rome, Italy: Food and Agriculture Organization.

Harizanova V, Stoeva A, Mohamedova M. 2009. Tomato leaf miner, Tuta absoluta (Povolny) (Lepidoptera: Gelechiidae)first record in Bulgaria. Agricultural Science and Technology, 1(3): 95-98

Howse P, Stevens JM, Jones, OT. 1998. Insects Pheromones and Their Use in Pest Management. Springer Netherlands https://doi.org/10.1007/978-94-011-5344-7

Kaoud, HA. 2014. Alternative Methods for the Control of Tuta absoluta. Global Journal of Multidisciplinary and Applied Sciences, 2(2): 41-46

Maluf WR, Barbosa LV, Santa-Cecilia, LVC. 1997. 2Tridecanone-mediated mechanisms of resistance to the South American Tomato Pinworm Scrobipalpuloides absoluta (Meyrick, 1917) (Lepidoptera-Gelechiidae) in Lycopersicon spp. Euphytica 93: 189-194. https://doi.org/10.1023/ A:1002963623325

Megido RC, Haubruge E, Verheggen, FJ. 2013. Pheromonebased Management Strategies to Control the Tomato Leafminer, Tuta absoluta (Lepidoptera: Gelechiidae). A review, 17(3): 475-482.

MOAD. 2016. Tomato Leaf miner [Tuta absoluta Meyrick]. Harihar Bhawan, Kathmandu: Ministry of Agriculture Development, Government of Nepal.

MOF. 2017. Agriculture Statistical Information on Nepalese Agriculture. Kathmandu, Nepal: Agribusiness Promotion and Statistics Division Agri-Statistics Section, Singha Durbar, Ministry of Agricultural Development, Government of Nepal.

Muniappan, R. 2015. Tuta absoluta: The Tomato Leafminer. Collaborative Research on Integrated Pest Management. United State of America.

NAPPO. 2013. Surveillance Protocol for the Tomato Leaf Miner, Tuta absoluta, for NAPPO Member Countries. North American Plant Protection Organization.

Potting RPJ, van der Gagg DJ, Loomans A, van der Straten M, Anderson H, Macleod A, Castrillon JMG, Cambra GV. 2013. Tuta absoluta, Tomato leaf miner moth or South American tomato moth. Netherland: Ministry of Agriculture, Nature and Food Quality, Plant Protection Service of the Netherlands.

Sah L. 2017. Tuta absoluta: A Serious and Immediate Threat to Tomato Production in Nepal. iDE Nepal, Kathmandu

Salama H, Fouda M, Ismail IA, Ebada I, Shehata, I. 2014. Life Table Parameters and Fluctuations in the Population Density of the Moth Tuta absoluta (Meyrick) - (Lepidoptera: Gelechiidae). Current Science International, 3(3): 252-259.

Sallam AA, Soliman MA, Khodary MA. 2015. Effectiveness of Certain Insecticides against the Tomato Leaf Miner Tuta absoluta (Meyrick) (Lepidoptera: Gelechiidae). Advances in Applied Agricultural Science, 3(2): 54-64.

Torres JB, Faria CA, Evangelista Jr WS, Pratissoli D. 2001. Within-plant distribution of leaf miner Tuta absoluta (Meyrick) immatures in processing tomatoes, with notes on plant phenology. International Journal of Pest Management, 47(3): 173-178. https://doi.org/10.1080/02670870010011091

USDA-APHIS. 2011. New Pest Response Guidelines: Tomato Leafminer (Tuta absoluta). 4700 River Road, Riverdale, Maryland, USA: USDA-APHIS-PPQ-EDP Emergency Management Maryland USA.

Witzgall P, Kirsch P., Cork A. 2010. Sex Pheromones and Their Impact on Pest Management. Journal of Chemical Ecology, 36(1): 80-100. https://doi.org/10.1007/s10886-009-9737-y

Zekeya N., Ndakidemi PA, Chacha M, Mbega E. 2016. Tomato Leafminer, Tuta absoluta (Meyrick 1917), an Emerging Agricultural Pest in Sub-Saharan Africa: Current and Prospective Management Strategies. African Journal of Agricultural Research, 12(6): 389-396. https://doi.org/ 10.5897/AJAR2016.11515 